UNRAM Law Review is licensed under a Creative Commons Attribution 4.0 International License, which permits unrestricted use, distribution, and reproduction in any medium, provided the original work is properly cited. p-ISSN: 2548-9267 | e-ISSN : 2549-2365, Open Access at : http://unramlawreview.unram.ac.id/index.php/ulr

\begin{tabular}{c|c|c|c|c|}
\hline Volume & Issue & Page & April & p-ISSN: 2548-9267 \\
4 & 1 & $17-25$ & 2020 & e-ISSN : 2549-2365
\end{tabular}

\title{
Analysis of Lawsuit Against the Factual Action which Conducted by Military after Law Number 30 Year 2014 Concerning Government Administration
}

\author{
Wahyu Purnomo \\ Airlangga University \\ E-mail:wepe2113@gmail.com \\ Rr. Herini Siti Aisyah \\ Airlangga University \\ E-mail: herini@fh.unair.ac.id \\ Thoriq Mulahela \\ Airlangga University \\ E-mail: th_riq@yahoo.com \\ Xavier Nugraha \\ Airlangga University \\ E-mail: xavier.nugraha-2015@fh.unair.ac.id
}

\begin{abstract}
The enactment of law Number 30 of 2014 on Government Administration has caused a paradigm shift under development of state administration decision (in short term known as KTUN). By virtue of article 87 of Law number 30 year 2014, KTUN was not only on the written form, but it can also be a factual act. This causes a change in the absolute competence of lawsuit on factual actions taken by the government from the district administrative court (PTUN). It is arises a question whether Article 87 of Law number 30 year 2014 also applies to claims for factual actions committed by the military. The formulation of problems in this research are 1) The position of a lawsuit against factual actions committed by the military before Law number 30 year 2014 and 2) the claim position against factual actions committed by the military after Law Number 30 Year 2014. This research is a doctrinal research by using a statute approach and conceptual approach. The result of the analysis found that the KTUN paradigm have change under Law number 30 year 2014, which does not affect the absolute competence of lawsuits for factual actions carried out by military, though a government were excluded as mentioned on Article 2 of Law Number 9 of 2004 on Amendments of Law Number 5 of 1986 concerning State Administrative Court. It was confirmed under Article 87 of Law 30/2014, which grammatically states that the only changes to the KTUN are those in Law 51/2009, Law 10/2004, and Law 5/1986. The application of lex specialist pictured under the act number 30 year 2014 which regulated the administrative decision by the government, however concerning the military only regulated under the act number 31 year 1997. Further, the absolute competence on handling the legal factual action by the military since the implementation of law number 30 year 2014 is still held in the district court.
\end{abstract}

Keywords: Law Number 30 Year 2014; Factual Actions by Military; Lawsuit. 
The changing paradigm of night watch state or in literature known as nacht wakerstaat or watchdog state to become a welfare state have marked by changes in state functions, initially, the state only served in the field of internal security which then turned into a welfare manager of citizens country (bestuurzorg). ${ }^{1}$ The split function of a state has caused the state to enter the realm of its citizen private life which has been in the context of night watch state where the citizen private life was isolated from the reach of a state. ${ }^{2}$ The state now has to put in the administrative system in order to manage all of the government activities and aims to create prosperity for its citizens. ${ }^{3}$

The aims on inclusion of administrative law in the citizen private life is to carry out the bestuurzorg function. It is requires an instrument which provide a basis for the legality for the country to implement. The instrument will serves as a basis to justify the state activities on the matters of private nature, it takes the form of administrative law system. ${ }^{4}$

"Noch suchen die Juristen eine definition zu ihrem Begreiffe Von Recht", a postulate stated by Immanuel Kant which means that a definition is not the only way to explain a concept, especially for legal concepts. ${ }^{5}$ The purpose of the postulate is actually to get an understanding of the concept of law that is not only to know the definition of a concept at first. However, understanding the definition of a legal concept simplifies the understanding of a concept, especially the legal concept where each phrase may easily have mislead in meaning. According to the law postulate, "ex falso quodlibet", in means that where the wrong concept leads to the wrong conclusion. ${ }^{6}$

In order not to misunderstand the concept of administrative law, several experts provides the definition of administrative law as follows:

1. According to Muhammad Rakhmat, the administrative law is a set of regulations that enables administration law to carry out the function of protection for the citizen who against the administrative actions under the administrative law as well as to protect the administrative law itself. Administrative law as a special relationship has made it possible to allow administrative official to carry out their specific duties. ${ }^{7}$

2. According to R. Abdoel Djamali, administrative law is the legal regulation that governing a set of legal regulations on administration which is the relationship between citizen and the government on the cause of country function. ${ }^{8}$

3. According to L.J.Van Apeldoorn, administrative law is the overall rule which must be observed by authorities who are entrusted with the task of government in carrying out their duties. ${ }^{9}$

From these various definitions, it can be concluded that administrative law examines all matters relating to the function of government (bestuur) which are excluded from the formation of laws (regelgeving) and justice (rechtspraak). ${ }^{10}$

1 Ray Robinson. (1984). "Restructuring the Welfare State: An Analysis of Public Expenditure". Journal of Social Policy, 15(1), p.1-21.

2 Yos Johan Utama. (2014). Pengertian Administrasi Negara dan Hukum Administrasi Negara. Tangerang Selatan: Universitas Terbukak, p. 3.

3 Ibid., p.4.

4 Tubagus Muhammad Nasarudin. (2016). “Asas dan Norma Hukum Administrasi Negara Dalam Pembuatan Instrumen Pemerintahan". Jurnal Hukum Novelty, 7(2), p.139-154.

5 Philipus M. Hadjon, dkk,(2005). Hukum Administrasi Negara, Yogyakarta: Gadjah Mada University Press, p.21.

6 Xavier Nugraha dan Ave Maria Frisa Katherina. (2019). "Tanggungjawab Promotor Perseroan Terbatas Terhadap Kon trak Pra Inkorporasi di Indonesia". Media Iuris, 2(1), p.137.

7 Muhamad Rakhmat.(2014). Hukum Administrasi Negara Indonesia. Bandung: Logoz Publishing, p. 18.

8 R.Abdoel Djamali.(1998). Pengantar Hukum Indonesia. Jakarta: PT RajaGrafindo Persada, p. 95.

9 L.J.Van Apeldoor.(1993).Pengantar Ilmu Hukum, Jakarta: Pt Pranandya Paramita,p.321.

10 Nur Asyiah. (2016). "Eksitensi Perlindungan Hukum Warga Negara Terhadap Tindakan Pemerintah Dalam Membuat Keputusan Administrasi Negara”. Samudra Keadilan, 1(1), p.46. 
In carrying out these government functions, one of the legal instruments which applicable is the administrative law decision (KTUN). KTUN's position in the administrative law is carried out in legal actions under the public nature, it is not private, because in this context legal actions are generally carried out unilaterally. ${ }^{11}$ The reason for this legal action is to be a onesided governmental act (eenzidjige publiekrechtiljk handelingen) because the emergence of a KTUN does not need to seek approval from the decision-maker or comes from the giver of the decision itself, although in some cases the KTUN comes from a request. ${ }^{12}$

KTUN as a unilateral government action argued that it will make the government decide arbitrarily. Therefore, the Administrative Court (PTUN) was born as a form of repressive legal protection against these unilateral government actions. ${ }^{13}$ PTUN presents as a "balance" between the great powers held by the government in making decisions with the public who accept a KTUN. The existence of PTUN as a "balancer" of great power possessed by the government in unilateral deciding is actually under the call of John Emerich Edward DalbergActon or commonly known as Lord Acton, where Power tends to corrupt, absolute power corrupts absolutely. ${ }^{14}$

Article 1 number 3 of Law Number 5 of 1986 Concerning Administrative Court (Law 5/1986), it is explained that the KTUN is included to be tested at PTUN, KTUN fulfills the following cumulative elements which are:

1. A written determination

2. It is issued by a State Administration Agency or Officer

3. It contains the legal actions of the State Administration according to the applicable laws and regulations,

4. There are concrete, individual, and final,

5. It causes legal consequences for a person or private legal entity

KTUN can be tested in PTUN, besides having to fulfill the requirements in Article 1 number 3 of Law 5/1986, it must not also be included in the scope of KTUN in Article 2 of Law Number 9 of 2004 Concerning Amendments to Law Number 5 of 1986 concerning Administrative Judiciary (Law 9/2004), which are:

a. Administration Decree is a civil law act;

b. Administration Decree is a general regulation;

c. Administration Decree still needs approval;

d. Administrative Decree issued depend on an article of the Criminal Law Act and the Criminal Procedure Code or other legislation which is criminal;

e. Administrative Decree issued based on the result in an examination of the judiciary depends on article applicable laws and regulation;

f. Administration Decree concern the administration of the Indonesian National Army;

g. The decision of the National Election Commission both at the central and regional levels about the results of the general election.

It shows that although the KTUN meets the elements in Article 1 number 3 of Law number 5 of 1986 and the KTUN listed in the scope of Article 2 of Law number 9 of 2004, however the KTUN cannot be tested at the administrative court (PTUN).

11 Nur Asyiah. (2016). "Kedudukan Keputusan Tata Usaha Negara Dalam Sistem Hukum Indonesia”. Pro Justitia, 1(1), p.68..

12 Ibid..

13 Hari Sugiharto dan Bagus Oktafian Abrianto. (2018). "Upaya Administratif Sebagai Perlindungan Hukum Bagi Rakyat". Arena Hukum, 11(1), p.29.

14 Aleksandra Cislak dkk. (2016). "Power Corrupts, but Control Does Not: What Stands Behind the Effects of Holding High Positions". Personality and Social Psychology Bulletin, 44(6), p.944. 
The KTUN which cannot be tested in PTUN, even though it meets the elements in Article 1 number 3 of Law number 5 of 1986 and a KTUN which is included in the scope of Article 2 of Law number 9 of 2004 which is an administrative law decision regarding administration of Indonesian National Army. The reason of Legist ratios which exclude an administrative law decision regarding the administration of Indonesian National Army in absolute competence of PTUN is because administrative law decision concerning the administration of the Indonesian National Army is absolute competencies of the Military Court as mentioned under Article 1 number 34 of Law Number 31 the Year 1997 concerning Military Justice (Law 31/1997). ${ }^{15}$ The background is because the military court is a special court which handles all of the administrative decision of the Indonesian National Army. A military court is different from an ordinary court for civilians because the Indonesian National Army ( TNI ) is the fact of the soldier who is in command, so a special court is needed where the judge is obliged to comprehend military law comprehensively which is different from the common law for civilians. ${ }^{16}$

In the development of law, there is a change in the paradigm of administrative law, where administrative law focused on providing services to the community, then there is an intensification that KTUN can be tested at PTUN. It is explained in Article 87 of Law Number 30 year 2014 Concerning Government Administration (Law 30/2014) is the enactment of this Law, the Administration Law Decree as referred to Law Number 5 of 1986 concerning Administrative Law Court as Amended by Law Number 9 Year 2004 and Law Number 51 Year 2009 must be interpreted as:

a. Written stipulations which included factual action;

b. Administration Decree Agency and/or Official in the executive, legislative, judicial and other state administration circles;

c. It depends on statutory Articles and AUPB;

d. Final is in the broader sense;

e. Decisions have the potential to cause legal consequences; and/or

f. Decisions apply to Citizens.

It can be seen that one of the juridical consequences of a change in the concept of KTUN in Law 30/2014 is factual action which included in KTUN. It means a lawsuit against government factual action (onrechtmatige overheidsdaad) which was once an absolute competence from District Court ${ }^{17}$ then moved to be an absolute competency of PTUN. It also confirmed under Supreme Court Circular Letter Number 4 of 2016 which in dictum E section of the Administration room number 1 states that:

Paradigm changing held in Administration Law Justice after the enactment of Law number 30 year 2014 concerning Administration (UU 30/2014)

1. Competency of the State Administrative Court

a. Authorities adjudicate cases in the form of lawsuits and requests

b. Authorities adjudicate acts violate the law by government act break the law which carried out by the holder of governmental authority (Agency and/or Government Official) commonly it referred to as onrechtmatige overheidsdaad (OOD).

The intensification of the KTUN concept which includes concrete action through Article 87 of Law 30/2014, have arises a legal issue "does the intensification apply to factual action committed by the military?" It is because, lexically, it can be seen in Article 87 of Law

15 There are some exceptions of KTUN which is although originating from TNI, it is not an absolute competence of Military Court as regulated in Article 2 of Law 31/1997.

16 Erni Agustina. (2009). "Prospeksi Peradilan Tata Usaha Militer dalam Sistem Peradilan di Indonesia". Jurnal Hukum, Edisi Khusus p.187-189.

17 Muhamad Adiguna Bimasakti. (2018).Unlawful Acts (PMH) By the Government / Onrechtmatige Overheidsdaad (OOD) From the Perspective of Government Administration Law. Yogyakarta: Deepblish, p. 23. 
30/2014, "the enactment of this Law, the Administration Decree as referred to Law Number 5 of 1986 concerning Administrative Court as already amended by Law Number 9 of 2004 and Law Number 51 of 2009 must be interpreted as ... "Does it include KTUN which is excluded in Article 2 of Law 9/2004? Does it make the lawsuit against factual actions carried out by the military move into absolute competence of the PTUN? Based on this background, the formulation of the problem in this study are:

1. The position of a lawsuit against factual action taken by the military before Law Number 30 Year 2014

2. The Status of Lawsuit against factual action taken by military after Law Number 30 Year 2014

\section{METHOD}

This research is doctrinal research. Doctrinal research is research that systematically presents legislation, analyzes the relationship between regulations, explains the obstacles that exist, and is possible to provide a prediction of future development. ${ }^{18}$ The research approaches which is used in this research are a statute approach and conceptual approach. The statute approach is an approach carried out by examining all the laws and regulations relating to the legal issues that handled. ${ }^{19}$ A conceptual approach is an approach which done by moving from the views and doctrines that develop in the science of law. In studying the views and doctrines, ideas will be found which emerge to the legal notion, legal concept, and legal principles which are relevant to the legal issues. ${ }^{20}$

\section{ANALYSIS AND DISCUSSION}

\section{The lawsuit of Factual Actions Made by the Military before Law Number 30 Year 2014}

Article 1 number 34 of Law 3/1997, it is the Administrative Decree of the Armed Forces of the Republic of Indonesia, hereinafter referred to as the Administrative Decree of Armed Forces, is a written determination issued by the Agency or Administrative Officer of Armed Forces of the Republic of Indonesia which contains legal action based on the applicable law and regulation, and relating to the implementation of guidance and use of the Armed Forces of the Republic of Indonesia and the management of state security in the fields of personnel, material, facilities, and services that are concrete, individual, and final, which cause legal consequences for people or civil legal entities. According to this Article, KTUN in the military context must meet the cumulative element as follows:

1. A written determination

2. It issued by the Agency or Administrative Officer of Armed Forces of the Republic of Indonesia

3. It contains legal action which depends on article of the applicable law and regulation and relating to the implementation of the development and use of Armed Forces of the Republic of Indonesia and the management of national security in personnel, material, facilities, and services

4. They are concrete, individual, and final

5. It causes a legal consequence for people or private legal entities.

18 Peter Mahmud Marzuki.(2011). Penelitian Hukum. Jakarta: Kencana Prenada Media Group, p. 35.

19 Ibid.,p.93.

20 Ibid.,p.94. 
According to the cumulative article in Article 1 number 34 of Law 3/1997, it can be seen that one of the requirements of KTUN in the military context is must be written in nature. This is confusing, even though it may cause harm to other parties, but is not on the written proof, for example, a factual act carried out by the military, it cannot be submitted to a military court. In a case, Article 265 paragraph (1) of Law 3/1997, mentioned that: "Civil person or legal entities who feel their interest are harmed by a Military Administration Decree (in the Act still using the term Armed Forces of the Republic of Indonesia, hereinafter used the term military), may submit a written claim to the competent Military Court which contains demand disputed Military Administrative Decree will be declared null or void, with or without demands for compensation and/or rehabilitation ". When there is a person or private legal who feels disadvantaged by a factual military act, then the person cannot submit a lawsuit to Military Court, because it has clashed with formal requirements as stipulated in Article 1 number 34 of Law 3/1997.

There is a remedy which applicable under Indonesian law for the event of loss causes by the military factual action which is occurred not on the written form, through the adherence of ius curian novit principle, where the judge is deemed to know all of the law so the Court may not refuse to examine and trial the cases in Indonesia in accordance with Article 5 paragraph (1) of Law Number 48 Year 2009 Regarding Judicial Power, as a juridical consequences, even though there is no existence of applicable legal rules, the judge is prohibited to reject the case which suited to them. ${ }^{21}$ Thus, although no specific rules are governing factual actions committed by the military, it does not mean the judge has the right to refuse to hear the case.

The problem arises when there is no specific regulation that regulated the factual actions committed by the military which is the absolute competence of the district court which has the right to hear the case. It turns out that in Indonesia, the adoption of the rechtspraak residual principle or the residual court principle, all cases are not regulated in statutory regulations are the competencies of district court absolute. ${ }^{22}$ It can be seen, for example in a civil lawsuit. There is no specific regulation governing civil lawsuit in Indonesia, so when there is a civil lawsuit, it is handled under the absolute competence of district court, although the characteristic of this civil lawsuit tends towards PTUN. ${ }^{23}$ For example, in Decision Number: 28 / Pdt.G / 2003 / PN. JKT.PST is often referred to as "Civil Lawsuit of Nunukan" where the Jakarta District Court granted the claim and stated that the lawsuit for civil lawsuit is an absolute competence from Jakarta District Court. ${ }^{24}$ Thus, the adoption of the principle of rechtspraak residuals by Indonesia, which is not specifically regulated about the lawsuit against factual actions committed by the military, is an absolute competence of the District Court.

In the absence of any special article related to the lawsuit against factual action committed by the military, the basis for a lawsuit can be used when it is going to a district court by referring to Article 1365 Burgelijk Wetbook (BW) which mentioned that "Every act violates the law and brings harm to other people, obliges the person who caused the loss because of his mistake to replace the loss ". Meanwhile, the elements in Article 1365 BW are 1) against the law (onrechmatig), 2) there is a loss, 3) there is a mistake (schuld- either intentionally or negligently), and 4) the existence of causality. Thus, only factual actions taken by the military that fulfill the elements in Article 1365 BW can be filed through the district court.

21 Yuristyawan Pambudi Wicaksana. (2018). "Implementasi Asas Ius Curia Novit Dalam Penafsiran Hukum Putusan Hakim Tentang Keabsahan Penetapan Tersangka". Lex Renaisssance, 3(1), p.89.

22 Muhamad Adiguna Bimasakti Op.cit.p. 26.

23 Abdul Fatah. (2013). "Gugatan Warga Negara Sebagai Mekanisme Pemenuhan Hak Asasi Manusia Dan Hak Konsti tusional Warga Negara". Yuridika, 28(3), p.300.

24 Ibid. 
The Impact of Law Number 30 the Year 2014 on Lawsuits against Factual Action Performed by Military: Does it Influenced?

It has been mentioned previously, by virtue of Article 2 letter (f) of Law 9/2004, the definition of KTUN which is related to KTUN in the military sector is not included in the definition of KTUN in Law 30/2014, so it cannot be sued through the administrative court (PTUN). It is because KTUN regarding the administration of the Indonesian National Army is not included in the definition of KTUN related to Law 9/2004. The provisions in Article 2 letter (f) of Law 9/2004 are exceptions to decisions classified as KTUN that have not been revoked (still valid). This means, systematically, despite extensification of the concept of KTUN in Law 30/2014, as long as limitations regarding the concept of KTUN in Article 2 of Law 9/2004 still exist, even though the KTUN is expanded, the exception is still valid including exceptions related to the Military KTUN. The following illustration is to make it easier:

Figure 1

KTUN before being expended

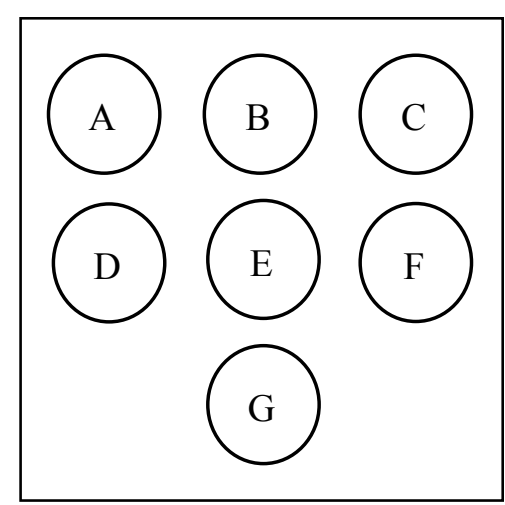

Figure 2

KTUN after being expended

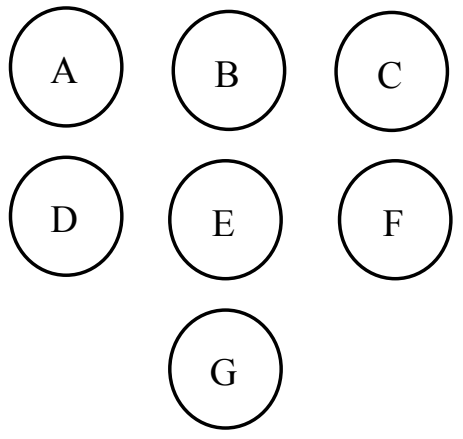

Notes:
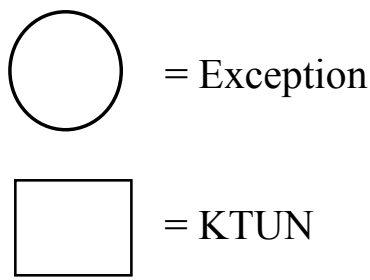

Moreover, although there is an intensification of the KTUN concept in Article 87 of Law $30 / 2014$, it can be seen that the context of Law 30/2014 only concerns about PTUN Law 
(Law 51/2009, Law 10/2004, and Law 5/1986), which is not the Law 31/1997. It can also be seen grammatically in Article 87 that "the enactment of this Law, Administration Decree as referred to in Law Number 5 of 1986 concerning Administrative Court as amended by Act Number 9 of the Year 2004 and Law Number 51 Year 2009 must be interpreted as ... "The word in that shows that the scope of Article 87 of Law 30/2014 is only limited in Law 51/2009, Law 10/2004, and Law 5/1986. ${ }^{25}$ Therefore, the expansion in Article 87 of Law $30 / 2014$ does not apply to Law 31/1997, so that claims against factual actions by the military do not turn into PTUN absolute competence. ${ }^{26}$

There are several opinions, where the enactment of Law 30/2014 has contributed to broaden the definition of KTUN under the Law 31/1997 because the Law 30/2014 is considered as lex specialist of Law 31/1997. In terms of determining laws are equally lex specialist systematic lex specialist principle can be used which is a derivative of the lex specialist derogat legi generali principle. ${ }^{27}$ As for those who are lex specialist systematic, those who arrange more fully within the framework of the special article, while those who are logical specialties are more general. ${ }^{28}$ In this context, what governs more fully and specifically related to the military KTUN is Law 31/1997, while Law 30/2014 is specifically the Administrative KTUN, further, according to the principle of lex specialist systematic did make the Law 31/1997 as applicable law.

\section{CONCLUSION}

The Implementation of Law 30/2014 has caused a paradigm shift in the KTUN. Under Article 87 of Law 30/2014, KTUN does not have to be written, but it can also be a factual act. This causes a change in absolute competence of lawsuits of factual action taken by the government from the district court to the Administrative Court.

The change in the KTUN paradigm by virtue of Law 30/2014 does not affect the absolute competence of lawsuits for factual action carried out by the military which is a government, since they are excluded as listed under Article 2 of Law 9/2004. It was confirmed under Article 87 of Law 30/2014, which grammatically states that only changed KTUN is those in Law 51/2009, Law 10/2004, and Law 5/1986. Also, the application of the systematic lex specialist principle, even though Law 30/2014 regulates KTUN by government, but what governs KTUN by the military is Law 31/1997, so the Law 31/1997 as the applicable law.

\section{Bibliography}

Books with an author:

Achmad Ali. (2012). Menguak Teori Hukum (Legal Theory) dan Teori Peradilan (Judicialprudence) Termasuk Interpretasi Undang-Undang (Legisprudence). Jakarta: Kencana

Eddy O.S. Hiariej. (2015). Prinsip-Prinsip Hukum Pidana Edisi Revisi, Yogyakarta, Cahaya Atma Pustaka, p.417.

L.J.Van Apeldoor.(1993).Pengantar Ilmu Hukum, Jakarta: Pt Pranandya Paramita.

Muhamad Adiguna Bimasakti. (2018). Perbuatan Melawan Hukum (PMH) Oleh Pemerintah/

25 Muhammad Adiguna Bimasakti Op.cit., p.41

26 Ibid

27 Eddy O.S. Hiariej.(2015). Prinsip-Prinsip Hukum Pidana Edisi Revisi, Yogyakarta, Cahaya Atma Pustaka, p.417.

28 Ibid. 
Onrechtmatige Overheidsdaad 9OOD) Dari Sudut Pandang Undang-Undang Administrasi Pemerintahan. Yogyakarta: Deepblish.

Muhamad Rakhmat. (2014). Hukum Administrasi Negara Indonesia. Bandung: Logoz Publishing.

Peter Mahmud Marzuki. (2011). Penelitian Hukum. Jakarta: Kencana Prenada Media Group.

Philipus M. Hadjon, dkk, (2005). Hukum Administrasi Negara, Gadjah Mada University Press, Yogyakarta.

R.Abdoel Djamali.(1998). Pengantar Hukum Indonesia. Jakarta: PT RajaGrafindo Persada.

Yos Johan Utama. (2014). Pengertian Administrasi Negara dan Hukum Administrasi Negara. Tangerang Selatan: Universitas Terbuka.

Journal articles:

Abdul Fatah. (2013). “Gugatan Warga Negara Sebagai Mekanisme Pemenuhan Hak Asasi Manusia Dan Hak Konstitusional Warga Negara". Yuridika, 28(3), p.293-303.

Aleksandra Cislak dkk. (2016). "Power Corrupts, but Control Does Not: What Stands Behind the Effects of Holding High Positions". Personality and Social Psychology Bulletin, 44(6), p.944-957.

Erni Agustina. (2009). "Prospeksi Peradilan Tata Usaha Militer dalam Sistem Peradilan di Indonesia". Jurnal Hukum, Edisi Khusus p.187-189.

Hari Sugiharto dan Bagus Oktafian Abrianto. (2018). "Upaya Administratif Sebagai Perlindungan Hukum Bagi Rakyat”. Arena Hukum, 11(1), p.24-47.

Nur Asyiah. (2016). "Eksitensi Perlindungan Hukum Warga Negara Terhadap Tindakan Pemerintah Dalam Membuat Keputusan Administrasi Negara". Samudra Keadilan, $1(1)$, p.44-54.

Nur Asyiah. (2016). "Kedudukan Keputusan Tata Usaha Negara Dalam Sistem Hukum Indonesia". Pro Justitia, 1(1), p.63-75.

Ray Robinson. (1984). "Restructuring the Welfare State: An Analysis of Public Expenditure". Journal of Social Policy, 15(1): 1-21

Tubagus Muhammad Nasarudin. (2016). “Asas dan Norma Hukum Administrasi Negara Dalam Pembuatan Instrumen Pemerintahan”. Jurnal Hukum Novelty, 7(2), p.139-154.

Xavier Nugraha dan Ave Maria Frisa Katherina. (2019). "Tanggungjawab Promotor Perseroan Terbatas Terhadap Kontrak Pra Inkorporasi di Indonesia”. Media Iuris, 2(1), p.127157.

Yuristyawan Pambudi Wicaksana. (2018). "Implementasi Asas Ius Curia Novit Dalam Penafsiran Hukum Putusan Hakim Tentang Keabsahan Penetapan Tersangka". Lex Renaisssance, 3(1), p.86-108.

Legislation:

Law Number 31 Year 1997 concerning Military Justice

Law Number 51 Year 2009 Concerning Second Amendements to Law Number 5 of 1986 about Administrative Judiciary

Law Number 30 Year 2014 Concerning Government Administration 